\title{
Sedative effects of intergroup contact on support for ethnic activism among Kosovo Albanians in Switzerland: The interplay of ethnic, national, and dual identification
}

\author{
Emanuele Politi $^{1,2}$ (D) | Adrienne Giroud ${ }^{1}$ | Eva G. T. Green ${ }^{1}$ (D) | Edona Maloku ${ }^{3}$ (D)
}

\author{
${ }^{1}$ Social Psychology Laboratory, University of \\ Lausanne, Lausanne, Switzerland \\ ${ }^{2}$ Center for Social and Cultural Psychology, \\ $\mathrm{KU}$ Leuven, Leuven, Belgium \\ ${ }^{3}$ Social Sciences Unit, Rochester Institute of \\ Technology, Prishtina, Kosovo \\ Correspondence \\ Emanuele Politi, University of Lausanne, \\ Lausanne, Switzerland. \\ Email: emanuele.politi@kuleuven.be
}

\begin{abstract}
A large body of research has demonstrated that intergroup contact is a powerful tool for reducing prejudice among majority group members. Yet, research among minority group members has revealed a more complex picture. The present contribution advances recent research on sedative effects of intergroup contact on support for ethnic activism, by investigating how identity dynamics undermine ethnic minorities' claims for better conditions and equal rights. More precisely, we disentangled the mediating roles played by reduced ethnic and increased national identification as a consequence of intergroup contact, while considering the moderating role of dual identification. Results from a cross-sectional study among an understudied immigrant minority, Kosovo Albanians in Switzerland, indicate that dual identification moderated the sedative effect of intergroup contact on support for ethnic activism via decreased ethnic identification, while no support for conditional processes of intergroup contact via increased national identification were found. Intergroup contact was linked to reduced ethnic identification, which in turn related to increased support for ethnic activism, but only when dual identification was low. Conversely, when dual identification was high, ethnic identification was unrelated to support for ethnic activism, and intergroup contact reduced ethnic activism directly. To conclude, we discuss the mobilizing role of dual identification, and reflect on how ethnic and national components of dual identities affect the politicization of stigmatized minorities.
\end{abstract}

\section{1 | INTRODUCTION}

While prejudice-reducing effects of positive intergroup contact have been amply evidenced (Hewstone \& Swart, 2011; Pettigrew \& Tropp, 2006), a growing body of research has demonstrated that such encounters participate in the reproduction of structural inequalities. Across different national contexts characterized by asymmetrical intergroup relations (e.g., Black South Africans, Palestinians in Israel, indigenous Maori in New Zealand, Latinos in the United States, Indigenous people in Mexico and Chile, Roma in Bulgaria, and Muslims in India), scholars have linked intergroup contact with reduced support for both equality principles (Dixon et al., 2010; Durrheim, Jacobs, \& Dixon, 2014; Hayward, Hornsey, Tropp, \& Barlow, 2017; Sengupta \& Sibley, 2013; see however Kauff, Green, Schmid, Hewstone, \& Christ, 2016) as well as reduced support for a large array of collective actions, ranging from petitions advancing minority rights to revolutionary resistance (Albzour, Penic, Nasser, \& Green, 2019; Çakal, Eller, Sirlopú, \& Pérez, 2016; Çakal, Hewstone, Schwär, \& Heath, 2011; Dixon et al., 2017; Hässler et al., 2020; Pereira, Green, \& Visintin, 2017; Reimer et al., 2017; Tropp, Hawi, Laar, \& Levin, 2012).

Reduced differentiation as a separate, disadvantaged group is one of the main explanations of the so-called sedative-or 
"paradoxical"-effect of intergroup contact on minorities' willingness to engage in ethnic activism (Wright \& Lubensky, 2009; see also Saguy, Tausch, Dovidio, \& Pratto, 2009 for other explanations). We suggest that sedative effects of intergroup contact among minority group members can be best understood in light of the identity dynamics resulting from intergroup contact. In line with the recent call for considering the intersectionality and compatibility of multiple collective identities appealing to minority group members (Curtin, Kende, \& Kende, 2016), the present study disentangles for the first time the different roles played by ethnic, national, and dual identification in explaining the sedative effects of intergroup contact on support for ethnic activism among Kosovo Albanians in Switzerland.

\section{1 | The interplay between ethnic and national identities, and ethnic activism of immigrant minorities}

Ethnic identification is at the heart of support for ethnic activism among minority group members, who need to stick together to claim better conditions and equal rights (Ellemers, Spears, \& Doosje, 1997; Zomeren, Spears, \& Leach, 2008; see also Ellemers, 1993; Tajfel \& Turner, 1979). Accordingly, social psychological literature has provided evidence for the relationship between ethnic identification and support for ethnic activism (Reysen, Slobodnikova, \& Katzarska-Miller, 2016). Chipeaux, Kulich, lacoviello, and Lorenzi-Cioldi (2017), for instance, demonstrated that French cross-border workers (i.e., French nationals living in France but working in Switzerland) identified less to France, as compared to co-ethnics living and working in France. In turn, reduced French identification among French border workers explained their lack of motivation to get involved in actions aimed to improve the situation of French people living in border regions of Switzerland (see also Derks, Laar, Ellemers, \& Raghoe, 2015). Because intergroup contact transforms intergroup boundaries, it is likely that the sedative effects of intergroup contact on reduced support for ethnic activism are best explained by reduced ethnic identification (Wright \& Lubensky, 2009). Studying collective action tendencies among Latino immigrants in the United States, for instance, Tausch, Saguy, and Bryson (2015) found that the negative relation between intergroup friendships and ethnic activism was mediated by decreased identification with the Latino community (see also Pereira et al., 2017; Saguy et al., 2009).

Concurrently, intergroup contact transforms intergroup boundaries also by increasing identification to a common superordinate group (Brown \& Hewstone, 2005; Dovidio, Gaertner, Shnabel, Saguy, $\&$ Johnson, 2010), such as the nation. Intergroup contact is therefore likely to also reduce support for ethnic activism through the mediating process of increased national identification. Indeed, increased national identification deviates minority group members' attention from political activities supporting their disadvantaged in-group. For example, Mähönen and Jasinskaja-Lahti (2015) demonstrated that Finnish national identification of Ingrian Finns (i.e., an historical Russian-speaking Finnish minority who migrated from Russia to Finland) was related to decreased support for ethnic activism in favor of the Russian-speaking minority, even when accounting for the relationship between ethnic identification and support for ethnic activism (see also Kulich, Lorenzi-Cioldi, \& lacoviello, 2015). These findings suggest that increased identification with the national majority group should mediate the negative link between intergroup contact and support for ethnic activism. Yet, to the best of our knowledge, the mediating role of national identification has never been tested in conjunction with sedative effects of intergroup contact.

Moreover, support for ethnic activism should not be solely related to the strength of ethnic and national identities taken in isolation, but it is likely to depend on the degree of their perceived compatibility (i.e., dual identity, see Dovidio et al., 2010; see also Benet-Martínez \& Haritatos, 2005). National identification fosters group members' entitlement to participate in the political debate of the host society (Simon \& Klandermans, 2001). Only when national identification is paired with dual identity, however, ethnic minority members feel entitled to defend the vested interests of their ethnic group (Scuzzarello, 2015; Simon \& Grabow, 2010; Simon \& Ruhs, 2008; see also Simon, Reichert, \& Grabow, 2013). Accordingly, Glasford and Dovidio (2011) exposed racial minority students in the United States to reports of intergroup encounters with Whites, and stressed either a definition of their identity as members of the national majority group (i.e., U.S. Americans) or a definition of their identity as dual. Their results indicate that the unique focus on national identity reduced participants' motivation to support social change, while the focus on dual identity enhanced it. Based on these considerations, it is therefore likely that dual identification dampens the negative effects of national identification on support for ethnic activism.

However, it is also likely that dual identification takes over the politicized potential of ethnic identification. Indeed, ethnic identification drives collective action intentions when group boundaries are perceived as impermeable and the majority group is depicted as immoral (Stott \& Drury, 2004; Wright \& Baray, 2012). Contradicting such premises, dual identification leads instead to greater perceived similarity and permeability between groups, as well as a more positive evaluation of the majority out-group (González \& Brown, 2003; Wright \& Lubensky, 2009). Accordingly, in a study conducted among Roma in Bulgaria, Pereira et al. (2017) found that the mobilizing role of ethnic identification was dampened by high levels of national identification as Roma-Bulgarians, which is a dual construct composed of nationalist feelings combined with an enduring ethnic distinctiveness. This suggests that dual identification dampens the politicized potential of ethnic identification, by increasing the perceived similarity and permeability of group boundaries (Di Bernardo et al., 2019).

Taken together, this overview suggests that dual identification constitutes a complex motive that dampens both the politicization effect of ethnic identification and the depoliticization effect of national identification. In other words, we expect dual identification to reduce the positive (negative) effects of ethnic (national) identification on support for ethnic activism, thereby nuancing the sedative effects of intergroup contact. To the best of our knowledge, no research to date has examined the interactive effects of ethnic and dual identification, nor the interactive effects of national and dual identification, underlying support for ethnic activism. 
FIGURE 1 Conceptual model of the effects of intergroup contact on support for ethnic activism as mediated by ethnic and national identification and moderated by dual identification. Dashed lines indicate paths that were tested but not predicted

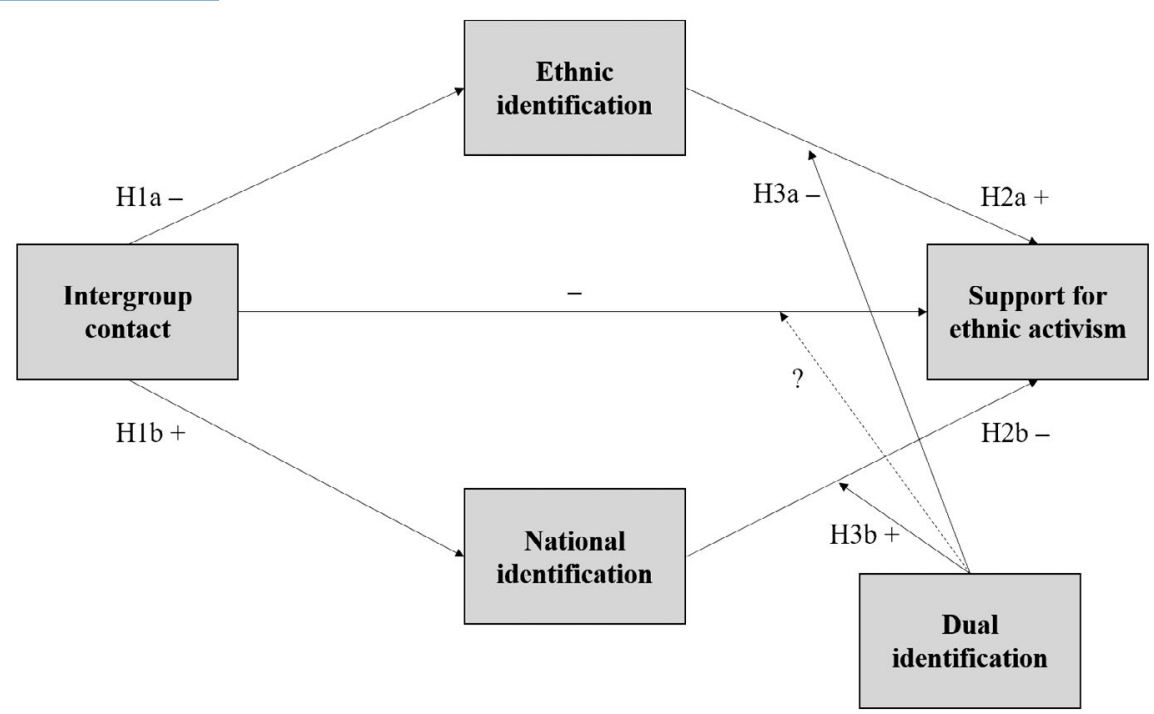

\section{2 | The present study}

Bridging research on sedative effects of intergroup contact and the duality of politicized collective identities, the present study makes a novel contribution to the literature on the sedative effects of intergroup contact on support for ethnic activism. First, we investigate whether intergroup contact reduces support for ethnic activism among an understudied immigrant minority. Second, we investigate whether intergroup contact reduces support for ethnic activism through the mediating role of ethnic and national identification. Third, we investigate whether dual identification moderates both the direct and the indirect effect of intergroup contact on reduced support for ethnic activism. We hypothesized that the previously evidenced negative relationship between intergroup contact and support for ethnic activism is explained through two processes. Intergroup contact should relate to reduced ethnic $(\mathrm{H} 1 \mathrm{a})$, and increased national $(\mathrm{H} 1 \mathrm{~b})$, identification. In turn, ethnic identification should be positively ( $\mathrm{H} 2 \mathrm{a})$, whereas national identification should be negatively $(\mathrm{H} 2 \mathrm{~b})$ related to support for ethnic activism. Furthermore, we hypothesized that dual identification dampens the positive relationship between ethnic identification and support for ethnic activism ( $\mathrm{H} 3 \mathrm{a}$ ). We also hypothesized that dual identification dampens the negative relationship between national identification and support for ethnic activism (H3b). In addition, we explore whether dual identification moderates the direct relationship between intergroup contact and support for ethnic activism. Figure 1 summarizes our hypotheses.

We investigated these processes in a cross-sectional study among Kosovo Albanians in Switzerland, an immigrant minority that has attracted little attention in social psychological research so far. Estimated between 150,000 and 170,000, Switzerland counts a considerably large share of Kosovo Albanians (Burri Sharani et al., 2010). According to the Swiss Federal Office of Migrations (OFM), the Kosovo Albanian diaspora represents one of the largest and historically most stigmatized immigrant groups in Switzerland (Burri Sharani et al., 2010; Wanner \& Steiner, 2012). The first migration wave in the 1960s was composed of seasonal workers, followed by a second wave in the 1990s during the war in Former Yugoslavia, mainly composed of asylum seekers. The arrival of the second wave created an image of a community that is perceived as burdening the economy and abuses the Swiss asylum and welfare system (Fibbi \& Truong, 2015). Probably because of their minority status, the ethnic identity of Kosovo Albanians in Switzerland is generally considered salient and they are perceived by Swiss authorities as self-segregating and politicized (Dahinden \& Moret, 2008).

Despite the stigmatization of the Kosovo Albanian community in Switzerland over 40,000 Kosovo Albanian have gone through the Swiss naturalization process, thereby reinforcing their economic, social, and political integration into the Swiss society (Bevelander, 2011; Hainmueller, Hangartner, \& Pietrantuono, 2015, 2017; Pantoja \& Gershon, 2006; Steinhardt \& Wedemeier, 2012). This ongoing process of upward mobility through citizenship acquisition coupled with the stigmatized image of Kosovo Albanians feeds public debates about the compatibility of Kosovar and Swiss cultural norms (Cola, Iseni, \& Brusa, 2012; see also Politi, Roblain, Roblain, Gale, Licata, \& Staerklé, 2020) and the related loyalty toward Swiss society (Nicolet \& Barth, 2018). This makes ethnic activism of Kosovo Albanian in Switzerland a fascinating topic for social psychological research.

\section{2 | METHOD}

\section{1 | Procedure and participants}

The study was conducted among Kosovo Albanian respondents living in the French and German-speaking regions of Switzerland. Respondents were contacted individually by a research student with Kosovo Albanian origins, or invited to complete the questionnaire by relatives or friends who had previously taken part in the study. Full anonymity was ensured. The final sample included 154 participants with 92 men (60\%) and a mean age of 32.2 years $(S D=11.03)$. Depending on their language proficiency and individual preference, respondents filled out either a French $(42.2 \%, n=65)$ or Albanian $(57.8 \%, n=88)$ version of the questionnaire. Since no questionnaire 
version was available in German, participants in the Germanspeaking region completed exclusively the Albanian version. ${ }^{1}$

The majority of the sample (76.6\%) was composed of participants who had grown-up in Switzerland. More precisely, 48 participants were either born in Switzerland or arrived before the age of 5 years. Thirty-two participants arrived during primary or secondary school. Conversely, 70 respondents arrived as adolescents ( $>15$ years old) or as adults in Switzerland. Overall, 61.4\% of the participants had Swiss citizenship. Forty percent of our respondents had a higher vocational or university degree, $50 \%$ a vocational or secondary education, and $7.8 \%$ primary education. One-third of the participants were students at the time of the survey, whereas $60 \%$ were employed and the remaining $10 \%$ were either unemployed, permanently disabled, retired, or reported household work for employment status. Over $80 \%$ of the participants judged their economic situation as either average $(50.3 \%)$ or comfortable (31.4\%) for the Swiss standards. Eighty-two percent were married or cohabitating with other Kosovo Albanians (against 18\% with a person of another "ethnicity"), confirming the cohesion within this minority group. The majority of the participants (83.1\%) were Muslim.

\subsection{Measures}

The questionnaire assessed intergroup contact, political behavior including support for ethnic activism, group identification, and integration into the Swiss society. Descriptive statistics are reported in Table 1.

\subsection{1 | Support for ethnic activism}

We computed a six-item index of support for ethnic activism ( $\alpha=.81)$. Two items were adapted from Simon and Ruhs (2008), and assessed support for improvements in the economic and education domains, "More needs to be done to improve the situation (according to Swiss standards) of Kosovo Albanians living in Switzerland." and "Better education and vocational training must be provided for young Kosovo Albanians living in Switzerland." One item was again adapted from Simon and Ruhs (2008), and assessed the right to vote in cantonal elections, "All Kosovo Albanians living in Switzerland should have the right to vote in cantonal elections." Finally, three items assessed the support for general improvements of the position, of equal job opportunities, and of access to resources for Kosovo Albanians, "I find it necessary to support the changes that will improve the position of Kosovo Albanians living in Switzerland." "I would support a law by which work opportunities equal to those of the Swiss will be guaranteed to Kosovo Albanians living in Switzerland." "I would support a law by which more equality in terms of resources, compared to people of Swiss origin, will be guaranteed to Kosovo Albanians living in Switzerland." The three first items were rated on 7-point scales

${ }^{1}$ Only 38 participants $(24.7 \%$ of the total sample) originated from German speaking regions, and generally reported lower proficiency with the local language as compared to participants who originated from French regions, $r(146)=-.23, p=.005$. The choice to administrate only an Albanian version of the questionnaire was therefore justified by the limited number of participants who might have opted for German as their preferred language. ranging from "would never support" to "would certainly support," whereas the three following were rated on a 7-point scale ranging from "strongly disagree" to "strongly agree." An exploratory factor analysis revealed that all items loaded on one factor.

As a control we also measured participants' general interest in politics with one item rated on a 7-point scale ranging from "strongly disagree" to "strongly agree" (Simon \& Klandermans, 2001). Average interest in politics was just above the scale-midpoint $(M=4.4, S D=1.98)$.

\subsection{2 | Intergroup contact}

Intergroup contact was assessed with intergroup friendship rated on a 4-point scale ranging from "none of my friends are Swiss" to "almost all my friends are (non-immigrant) Swiss." ${ }^{2}$

\subsection{3 | Dual identification}

Dual identification was measured with four items $(\alpha=.71)$ adapted from previous studies and rated on a 7-point scale ranging from "strongly disagree" to "strongly agree" (e.g., "I feel I belong to both the Swiss and the Kosovo Albanians." "I feel at ease with both Albanian culture and Swiss culture," see Simon \& Grabow, 2010).

\subsubsection{Ethnic and national identification}

We used single-item indicators of both ethnic and national identification, "I identify with Kosovo Albanians living in Switzerland." and "I identify with the Swiss." respectively, rated on 7-point scale ranging from "strongly disagree" to "strongly agree" (Jenkins, Reysen, \& Katzarska-Miller, 2012).

\section{3 | RESULTS}

\section{1 | Descriptive statistics}

Table 1 summarizes descriptive statistics for the main variables. Participants reported above scale midpoint scores of identification with Kosovo Albanians. Identification with the ethnic group was significantly stronger than national identification, $t(150)=5.07$,

\footnotetext{
${ }^{2}$ The questionnaire included additional measures that were not included in the main models. Intergroup contact with nonimmigrant Swiss was indeed measured with three different items tapping the quantity of close Swiss friends, measured on a 4-point scale, and both the quantity and quality of casual contact with members of the Swiss majority, measured on a 7-point scale. Since the scale of intergroup friendship differed from the others, and the internal consistency among the three items was modest $(\alpha=.63)$ and below acceptable thresholds of reliability (Cortina,1993), only intergroup friendship was retained to test our main hypotheses. Indeed, previous studies demonstrated that intergroup friendship is most critically related to decreased support for ethnic activism among minority group members (Hässler etal.,2020; Tausch etal.,2015). When the aggregate score was used to test our main hypotheses, the interpretation of results remained the same, but the effect size generally decreased. Whereas the relation between intergroup contact and ethnic identification became insignificant, the relation between intergroup contact and national identification became significant.
} 
TABLE 1 Descriptive statistics and correlations of main explanatory and outcome variables

\begin{tabular}{llllllll} 
Variables & Means & SD & 1. & 2. & 3. & 4. & 5. \\
\hline 1. Support for ethnic activism & 6.04 & 0.95 & 1 & & & & \\
2. Ethnic identification & 5.59 & 1.57 & $.26^{* *}$ & 1 & & & \\
3. National identification & 4.64 & 1.84 & -.06 & .13 & 1 & & \\
4. Dual identification & 5.82 & 1.09 & .06 & -.06 & $.41^{* *}$ & 1 & \\
5. Intergroup contact & 2.45 & 0.77 & $-.20^{*}$ & $-.21^{* *}$ & $.21^{*}$ & $.28^{* *}$ & 1 \\
\hline
\end{tabular}

Note: All items were rated on a 7-points scales, except for intergroup contact, rated on a scale ranging from 1 to 4 .

${ }^{*} p<.05$ (two-tailed); ${ }^{* *} p<.01$ (two-tailed).

$p<.001$. Mean support for ethnic activism was significantly above scale-midpoint, $t(153)=15.46, p<.001$. Moreover, $\operatorname{men}(M=5.52$, $S D=1.05)$ generally supported ethnic activism more than women $(M=5.02, S D=1.01), F(152,1)=4.54, p=.04, \eta_{p}^{2}=.029$. Older participants supported ethnic activism slightly more than younger participants, $r_{\text {activism-age }}=.26, p=.001$. In line with the literature on sedative effects, intergroup contact correlated negatively with both ethnic identification and support for ethnic activism. Conversely, intergroup contact correlated positively with national identification. National identification and dual identification, in turn, were unrelated to support for ethnic activism. Conversely, ethnic identification correlated positively with support for ethnic activism.

\section{2 | Hypothesis testing}

In order to test our set of hypotheses, we conducted a relative conditional process analysis (Hayes, 2018) on the two hypothesized pathways separately. Statistical tests for the regression analyses presented hereafter were two-tailed with alpha set at .05. Differences in degrees of freedom between regression models are due to missing data. Age, gender, citizenship, economic level, education, general interest in politics, and language proficiency were used as control variables. ${ }^{3}$ The moderated mediation models were tested using PROCESS model $15 .{ }^{4}$

\footnotetext{
${ }^{3}$ We chose to control for each of the aforementioned variables, instead of the language of the questionnaire. In fact, preliminary analyses revealed that language confounds multiple dimensions, related to both acculturation orientations and sociodemographic characteristics, as well as data collection location as on the German-speaking region the questionnaire administered in Albanian. On the one hand, the choice of questionnaire language (Albanian as reference category) correlates with intergroup contact, $r(151)=.33, p<.001$, ethnic identification, $r(151)=-.28, p=.001$, dual identification, $r(151)=.16, p=.04$, support for ethnic activism, $r(151)=-.39, p<.001$. On the other hand, it correlates with citizenship, $r(150)=.34$, $p<.001$, age, $r(149)=-.52, p<.001$, socialization in Switzerland, $r(148)=.36, p<.001$, economic vulnerability, $r(150)=.18, p=.02$, education level, $r(151)=.24, p=.003$, and language proficiency, $r(151)=.65, p<.001$. When language of the questionnaire was inserted as covariate, the result pattern remained the same and estimates stayed robust. Nevertheless, the main effect of intergroup contact on ethnic identification became nonsignificant.

${ }^{4} \mathrm{~A}$ joint model grouping ethnic and national identification in a parallel double moderated mediation was also examined. The result pattern remained the same. This model should be interpreted with caution, however: The sample size is underpowered for testing a double moderated mediation model, thus resulting in biased estimates. Moreover, the observed covariation between ethnic and national attachment as moderated by dual identification violates the underlying assumption of orthogonality between parallel mediators (Hayes, 2018). Indeed, the relation between ethnic and national identification was qualified by a cross-over interaction with dual identification, $b=.34$ (.07), $p<.001,95 \%$ $\mathrm{Cl}[19, .48]$. Although the bivariate correlation between the two identity measures was weak, $b=.10(.08), p=.23,95 \% \mathrm{Cl}[-.06, .26]$, a test of simple effects revealed that ethnic identification was negatively related to national identification for low levels of dual identification, $b=-.27(.13), p=.04,95 \% \mathrm{Cl}[-.52,-.02]$, but positively related to national identification for high levels of dual identification, $b=.47(.10), p<.001,95 \% \mathrm{Cl}[.26, .67]$.
}

\subsection{1 | Sedating effects through reduced ethnic identification}

The first pathway was tested by means of a moderated mediation model, which included ethnic identification as mediator of the effect of intergroup contact on support for ethnic activism. Dual identification was used as moderator of total, direct and indirect effects. First, we calculated the total effect of intergroup contact on support for ethnic activism, and we entered dual identification as moderator. Then, we estimated the conditional indirect effects, by introducing ethnic identification as a mediator ( $\mathrm{H} 1 \mathrm{a}$ and $\mathrm{H} 2 \mathrm{a})$, and tested whether the indirect effect was moderated by dual identification (H3a). Full information about the effect of control variables on both ethnic identification and support for ethnic activism can be found in Table 2.

As a first step, intergroup contact was regressed on support for ethnic activism. The model was significant, $F(10,136)=3.56$, $p<.001, R^{2}=.21$. The main effect of intergroup contact on support for ethnic activism was nonsignificant, $b=-.13(.11), p=.24,95 \% \mathrm{Cl}$ $[-.36, .09]$. Yet, dual identification moderated the relation between intergroup contact and support for ethnic activism, $b=-.19$ (.08), $p=.02,95 \% \mathrm{Cl}[-.35,-.02]$. A test for simple effects (Figure 2) showed that intergroup contact was negatively related to support for ethnic activism when dual identification was high (centered at one standard deviation above the mean), $b=-.34$ (.14), $p=.01,95 \%$ $\mathrm{Cl}[-.61,-.07]$, but not when dual identification was low (centered at one standard deviation below the mean), $b=.07$ (.15), $p=.63,95 \% \mathrm{Cl}$ $[-.23, .38]$. The Johnson-Neyman technique informed us about the region where the conditional effect of intergroup contact on support for ethnic activism became significant (Hayes, 2018; Johnson \& Neyman, 1936). Results revealed that intergroup contact reduced support for ethnic activism among $59 \%$ of the cases, namely those participants who reported scores of dual identification higher than the threshold value of $5.95 .^{5}$

${ }^{5}$ No hypothesis was formulated for the interactive effect of intergroup contact and dual identity. Nevertheless, this finding highlights the ambivalent role of dual identity on support for ethnic activism. Whereas dual identity was directly related to support for ethnic activism, it was also driving the sedative effects of intergroup contact. Supporting this pernicious interactive effect, additional exploratory analyses using measures that were not included in the main models showed that dual identification was also related to increased prescription of national culture adoption for immigrants, $r(152)=.32, p<.001$, and cognitive representations of Kosovars and Swiss as incorporated in the same category, $r(143)=.30, p<.001$ 
TABLE 2 Unstandardized coefficients and standard errors of all variables regressed on ethnic identification and support for ethnic activism

\begin{tabular}{|c|c|c|c|c|}
\hline & \multicolumn{2}{|c|}{$\begin{array}{l}\text { Ethnic } \\
\text { identification } \\
\text { (Me 1) }\end{array}$} & \multicolumn{2}{|c|}{$\begin{array}{l}\text { Support for } \\
\text { ethnic activism } \\
\text { (Y) }\end{array}$} \\
\hline & B & $S E$ & $B$ & $S E$ \\
\hline Age & -.007 & .01 & $.01^{\dagger}$ & .008 \\
\hline Gender & .29 & .30 & .02 & .18 \\
\hline Citizenship & -.07 & .15 & $-.16^{\dagger}$ & .08 \\
\hline Language proficiency & -.04 & .20 & -.11 & .12 \\
\hline Economic level & .15 & .18 & .08 & .10 \\
\hline Education level & -.03 & .10 & -.08 & .06 \\
\hline Interest in politics & $.19^{* *}$ & .07 & .02 & .04 \\
\hline Intergroup contact (X) & $-.39^{*}$ & .19 & -.08 & .11 \\
\hline $\begin{array}{l}\text { Ethnic identification } \\
\text { (Me 1) }\end{array}$ & & & $.14^{* *}$ & .05 \\
\hline Dual identification (Mo) & & & $.13^{\dagger}$ & .07 \\
\hline Contact $\times$ Dual & & & $-.23^{* *}$ & .08 \\
\hline Ethnic $\times$ Dual & & & $-.10^{*}$ & .04 \\
\hline
\end{tabular}

Note: $\mathrm{X}$, independent variable; Me, mediator variable; Mo, moderating variable; $\mathrm{Y}$, dependent variable. Estimates extracted from a moderated mediation model using PROCESS Version 3, model 15.

${ }^{\dagger} p \leq .10 ;{ }^{*} p \leq .05 ;{ }^{* *} p \leq .01$

As a second step, we tested whether the conditional effect of intergroup contact was mediated by ethnic identification. We inserted all meaningful interactions between focal predictors and dual identification. Compared to the model without the mediator, ethnic identification, and its interaction with dual identification accounted for a significant increase of the total explained variance of ethnic activism, $\Delta F(2,135)=5.58, p=.005, \Delta R^{2}{ }_{a d j}=.06 .^{6}$ In line with $\mathrm{H} 1 \mathrm{a}$, we found that intergroup contact was related to decreased ethnic identification, $b=-.39$ (.19), $p=.04,95 \% \mathrm{Cl}[-.76$, -.02]. Supporting $\mathrm{H} 2 \mathrm{a}$, ethnic identification fostered support for ethnic activism, $b=.14$ (.05), $p=.006,95 \% \mathrm{Cl}$ [.04, .23]. Moreover, the main effect of ethnic identification on support for ethnic activism was moderated by dual identification, $b=-.10(.04), p=.02$, $95 \% \mathrm{Cl}[-.18,-.01]$. A test for simple effects (Figure 3 ) showed that ethnic identification was related to increased support for ethnic activism when dual identification was low (-1 SD), $b=.24$ (.07), $p=.001,95 \% \mathrm{Cl}[.10, .39]$, but not when dual identification was high (+1 SD), $b=.03(.06), p=.61,95 \% \mathrm{Cl}[-.09, .15]$. The JohnsonNeyman technique evidenced that ethnic identification was linked to increased support for ethnic activism among $50 \%$ of the cases, namely those participants reporting scores of dual identification below 6.16. Put differently, dual identification took over ethnic

${ }^{6} \mathrm{As}$ a robustness test, the same hierarchical regression model was estimated including national identification as covariate. In line with a moderation mediation model the interaction between ethnic and dual identification shrank but remained significant, $b=-.09(.05), p=.05,95 \% \mathrm{Cl}[-.18,-.0001]$ identification as a politicized identity, so ethnic identification was unrelated to support for ethnic activism when dual identity was high.

Pursuing the relative conditional process analysis (Hayes, 2018), we estimated indirect effects for two cutting points in the distribution of dual identification. As hypothesized ( $\mathrm{H} 3 \mathrm{a})$, the indirect effect through ethnic identification was significant when dual identification was low (-1 SD), $b=-.09$ (.05), 95\% Cl [-.20, -.007], but not when dual identification was high (+1SD), $b=-.01$ (.03), 95\% $\mathrm{Cl}[-.09$, .04]. Because, dual identification dampened the positive effects of ethnic identification on support for ethnic activism, the sedative effects of intergroup contact through decreased ethnic identification were not observed among dual identifiers.

\subsection{2 | Sedating effects through increased national identification}

The second pathway was tested by means of a moderated mediation model, which included national identification as mediator of the effect of intergroup contact on support for ethnic activism ( $\mathrm{H} 1 \mathrm{~b}$ and $\mathrm{H} 2 \mathrm{~b}$ ). Dual identification was used as moderator of total, direct and indirect effects. As the total effect of intergroup contact on support for ethnic activism was reported above, we focus on the conditional indirect effects, and tested whether the indirect effect was moderated by dual identification ( $\mathrm{H} 3 \mathrm{~b}$ ) (see Table 3 for full information of the model).

We found only marginal evidence for $\mathrm{H} 1 \mathrm{~b}$, that is, for the relation between intergroup contact and national identification, $b=.35$ (.21), $p=.10,95 \% \mathrm{Cl}[-.07, .77]$. Also, national identification did not impair support for ethnic activism per se (contrary to $\mathrm{H} 2 \mathrm{~b}$ ), $b=-.10(.11), p=.40,95 \% \mathrm{Cl}[-.32, .13]$. Yet, the main effect of national identification on support for ethnic activism was moderated by an interaction with dual identification, $b=.09$ (.04), $p=.04,95 \%$ $\mathrm{Cl}[.003, .17]$. A test for simple effects (Figure 4) showed that national identification was marginally related to reduced support for ethnic activism when dual identification was low $(-1 S D), b=-.12$ (.07), $p=.07,95 \% \mathrm{Cl}[-.26, .01]$, but not when dual identification was high (+1 SD), $b=.07$ (.06), $p=.30,95 \% \mathrm{Cl}[-.06, .19]$. Indeed, national identification was linked to reduced support among $12 \%$ of cases, namely those participants reporting levels of dual identification lower than the threshold value of 4.11

Because of the weak effect sizes and reduced region of significance, national identification and its interaction with dual identification did not account for a significant increase of the total variance explained of support for ethnic activism, $\Delta F(2,133)=2.23, p=.11$, $\Delta R_{a d j}^{2}=.03 .^{7}$ We nevertheless estimated indirect effects for low and high dual identification separately. Against $\mathrm{H} 3 \mathrm{~b}$ the indirect effect through national identification was nonsignificant both when

${ }^{7}$ As a robustness test, the same hierarchical regression model was estimated including ethnic identification as covariate. When ethnic identification was controlled for the interaction between national and dual identification shrank and became nonsignificant, $b=.06(.04), p=.18,95 \% \mathrm{Cl}[-.03, .15]$ 


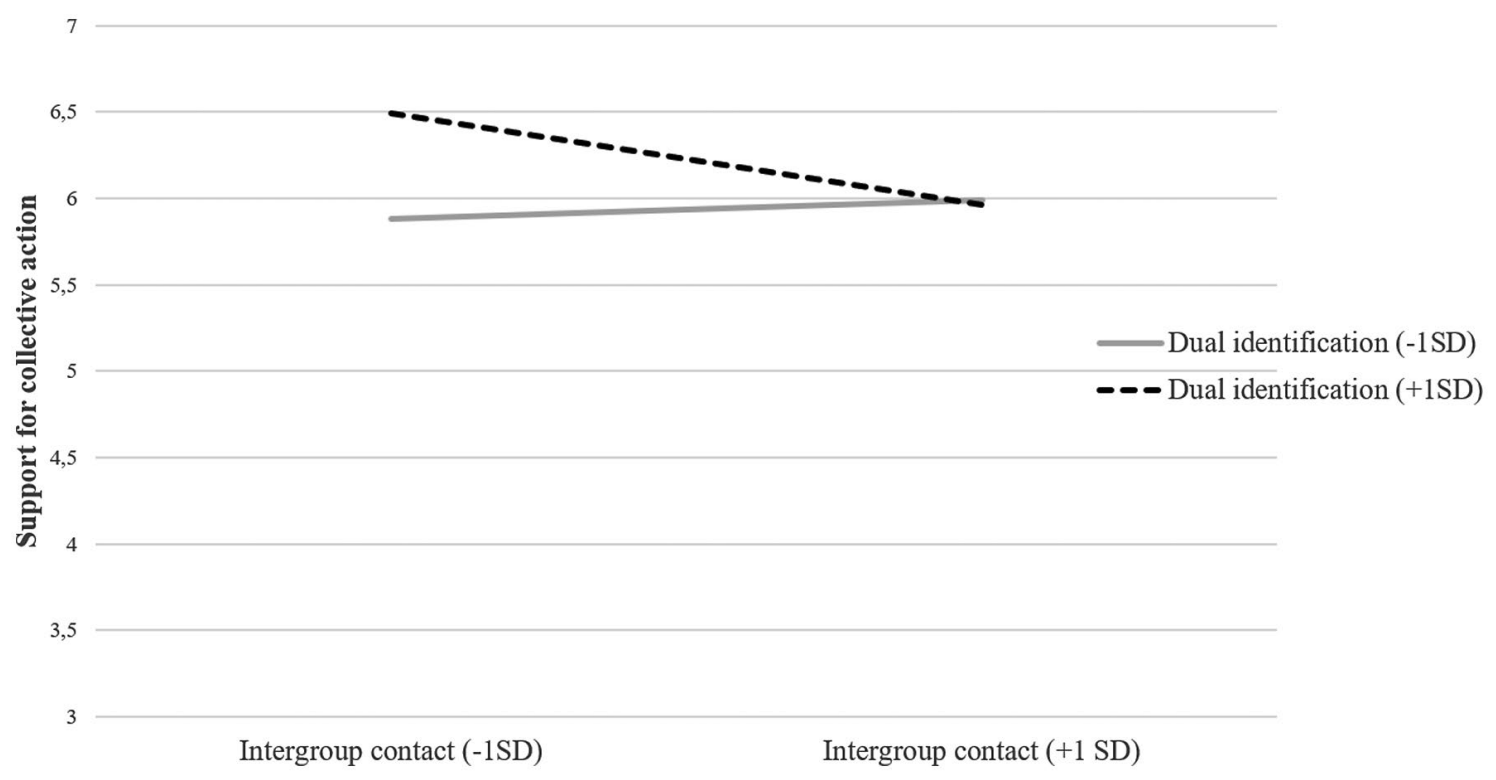

FIGURE 2 Decomposition of the interaction effect between intergroup contact and dual identification on support for ethnic activism

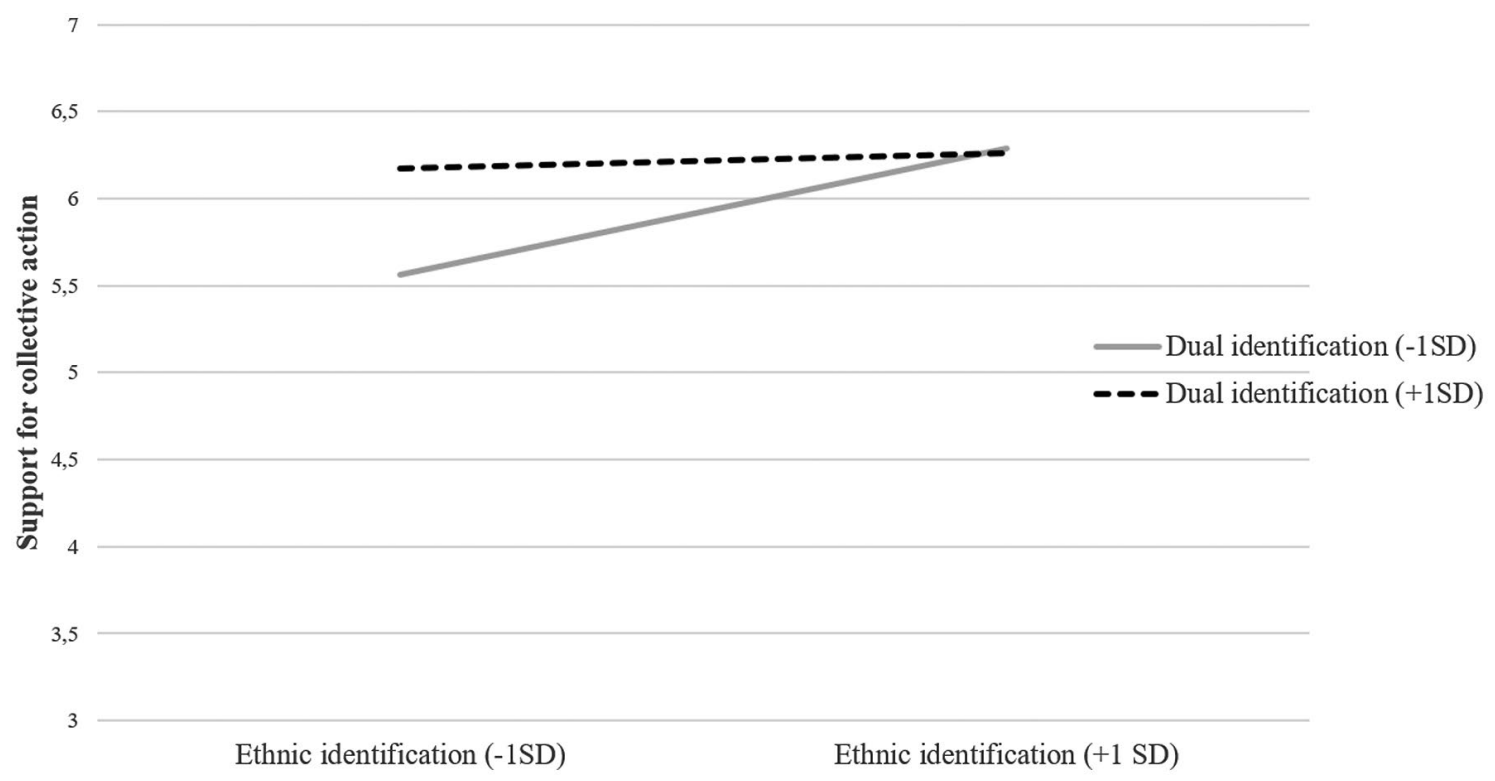

FIGURE 3 Decomposition of the interaction effect between ethnic and dual identification on support for ethnic activism

dual identification was low (-1 SD), $b=-.04(.04), 95 \% \mathrm{Cl}[-.13$, .008 ], and when dual identification was high (+1 SD), $b=.02$ (.03), $95 \% \mathrm{Cl}[-.03, .10]$. Although dual identification dampened the incompatibility between national identification and support for ethnic activism, we found only scant and inconclusive evidence about the sedative effects of intergroup contact through increased national identification.

\section{DISCUSSION}

The present study brings together literatures on both the sedative effect of intergroup contact and the duality of politicized collective identities, to investigate support for ethnic activism among minority group members. More precisely, we examined whether intergroup contact undermines support for ethnic activism through ethnic and national identification, while considering dual identification. The contribution of the study is threefold: First, we tested sedative effects of intergroup contact among a minority group that has been hardly studied so far, that is, Kosovo Albanians living in Switzerland. Overall, our results showed that intergroup contact with majority Swiss members undermines their support for ethnic activism. Second, we tested whether ethnic (Kosovo Albanian) and national (Swiss) identification mediate the sedative effects of intergroup contact on support for ethnic activism. Our results showed that intergroup contact undermines support for ethnic activism via reduced ethnic identification. 


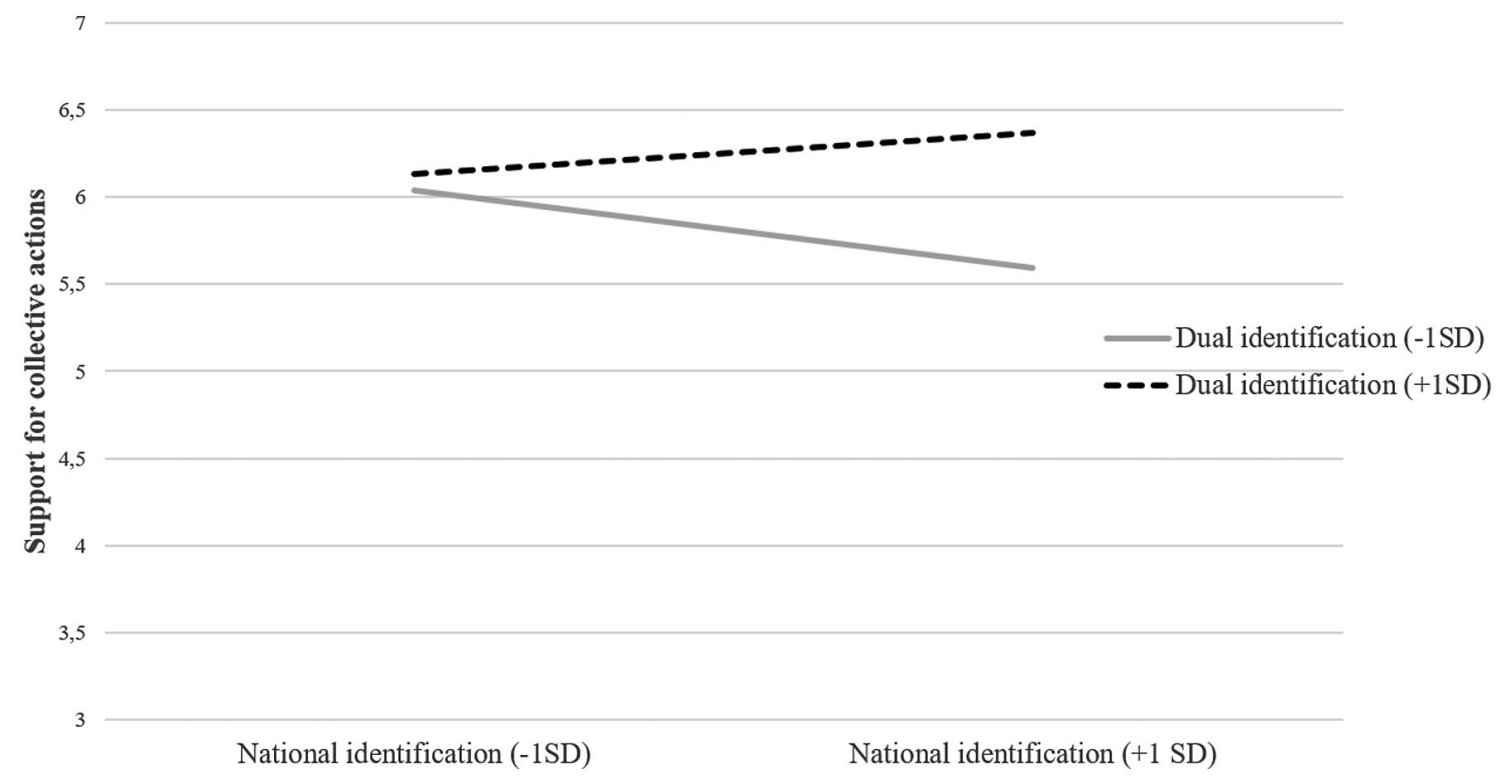

FIGURE 4 Decomposition of the interaction effect between national and dual identification on support for ethnic activism

TABLE 3 Unstandardized coefficients and standard errors of all variables regressed on national identification and support for ethnic activism

\begin{tabular}{|c|c|c|c|c|}
\hline & \multicolumn{2}{|c|}{$\begin{array}{l}\text { National } \\
\text { identification } \\
\text { (Me 2) }\end{array}$} & \multicolumn{2}{|c|}{$\begin{array}{l}\text { Support for } \\
\text { ethnic activism } \\
\text { (Y) }\end{array}$} \\
\hline & B & $S E$ & B & SE \\
\hline Age & -.005 & .02 & $.02^{\dagger}$ & .008 \\
\hline Gender & .42 & .34 & -.05 & .18 \\
\hline Citizenship & $.42^{*}$ & .16 & $-.16^{\dagger}$ & .09 \\
\hline Language proficiency & .18 & .23 & -.11 & .12 \\
\hline Economic level & .22 & .21 & .11 & .11 \\
\hline Education level & .02 & .12 & -.05 & .06 \\
\hline Interest in politics & -.04 & .08 & .03 & .04 \\
\hline Intergroup contact (X) & $.35^{\dagger}$ & .21 & -.10 & .11 \\
\hline $\begin{array}{l}\text { National identification } \\
(\mathrm{Me} 2)\end{array}$ & & & -.03 & .05 \\
\hline Dual identification (Mo) & & & $.20^{*}$ & .08 \\
\hline Contact $\times$ Dual & & & $-.30 * *$ & .10 \\
\hline National $\times$ Dual & & & $.09^{*}$ & .04 \\
\hline
\end{tabular}

Note: $\mathrm{X}$, independent variable; $\mathrm{Me}$, mediator variable; Mo, moderating variable; $\mathrm{Y}$, dependent variable. Estimates extracted from a moderated mediation model using PROCESS Version 3, model 15.

${ }^{\dagger} p \leq .10 ;{ }^{*} p \leq .05 ;{ }^{* *} p \leq .01$.

Conversely, we did not find evidence that intergroup contact undermines support for ethnic activism via increased national identification as we had predicted. Third, we tested whether dual identification moderates both direct and indirect sedative effects of intergroup contact on support for ethnic activism. Our results showed that intergroup contact undermines ethnic activism both for high dual identifiers (direct effect), and for low dual identifiers (indirect effect).
While elucidating the identity dynamics responsible for the sedative effects of intergroup contact, boundary conditions where dual identification enhances support for ethnic activism were also revealed (Simon \& Grabow, 2010; Simon \& Ruhs, 2008). For instance, the direct sedative effect of intergroup contact on support for ethnic activism only occurred for high dual identifiers, so that frequent contact with national majority members depoliticized dual identity. Despite an achieved dual self-construct, Kosovo Albanians who reported good relations with the Swiss majority were reluctant to engage in ethnic activism to improve the status of the Kosovar minority in Switzerland. Although not predicted, this finding supports the idea that reduced salience of group boundaries and increased similarity between in-group and out-group during intergroup contact disempowers minority group members, and diverts them away from the vested interest of their ethnic group (Di Bernardo et al., 2019; see also Harwood, Hewstone, Paolini, \& Voci, 2005).

To date the effects of dual identification on support for ethnic activism have always been investigated in isolation, thereby neglecting the interactive effects between national and ethnic identifications on the one hand, and their perceived compatibility on the other hand. Our results call for a more comprehensive investigation of the mobilizing role of dual identity, based on how ethnic and national identity components are reconciled in the self-concept. On the one hand, dual identification Dampened the incompatibility between national identification and support for ethnic activism. As compared to low dual identifiers, when high levels of national identification were paired with a dual identity, participants were less reluctant to support ethnic activism. Under these circumstances, not only Kosovo Albanians were feeling entitled to participate in the political debate, but also to defend the vested interest of their ethnic group. On the other hand, dual identification took over the politicized potential of ethnic identification. Dual identifiers supported ethnic activism irrespective of their level of ethnic identification. Accordingly, the mobilizing effect of ethnic identification was 
dampened among Kosovo Albanians who incorporated subordinate ethnic and superordinate national identities within a dual self-concept.

This pattern of results raises questions about the meaning attributed to dual identity by our participants. Whereas both intergroup contact and national identification correlated positively with dual identity, no correlation was found between dual identity and ethnic identification. The Swiss national identity component within the dual identity construct was particularly prominent in our sample. In line with the arguments provided by Wright and Lubensky (2009), it is plausible that dual identification gradually brings minority group members closer to the advantaged group's superordinate identity, thereby reducing separation and group distinctiveness. This is particularly likely for immigrants who are undergoing a process of acculturation in the receiving society (Berry, Phinney, Sam, \& Vedder, 2006; Phinney, 1990). Under these circumstances, the ethnic and national components of dual identities are therefore not symmetrical. The achieved national identity builds instead upon (and perhaps move away from) the inherited ethnic identity (Benet-Martínez \& Haritatos, 2005; Martiny, Froehlich, Deaux, \& Mok, 2017).

It follows that the articulation of ethnic and national identities within a dual self-concept is a complex process, the dual identity content being tied up with historical considerations and the general societal climate in which immigrants' acculturation is embedded (Hopkins \& Kahani-Hopkins, 2006). On the one hand, identity adjustments following intergroup contact depend on the meaning and value attributed to the inherited ethnic identity. For instance, the Kosovo Albanian identity is already an uneasy articulation between ethnic (i.e., Albanian) identity and a new national (i.e., Kosovar) identity (Maloku, Derks, Laar, \& Ellemers, 2016). Immigrant minorities originating from post-conflict societies, thus have specific ethnic and national identity concerns that may shape dual identification strategies in receiving societies. On the other hand, identity adjustments following intergroup contact also depend on acculturation expectations and inclusion goals within the receiving society. For instance, Switzerland has a strong democratic culture, but little readiness to accommodate cultural diversity and minority rights (Guimond, Sablonnière, \& Nugier, 2014; Koopmans, Statham, Giugni, \& Passy, 2005). Because of the specificity of this societal climate, it is therefore likely that national identification results in a process of political absorption and reduced support for ethnic activism among minority group members (Kolbe \& Crepaz, 2016; Politi, Chipeaux, Chipeaux, Lorenzi-Cioldi, \& Staerklé, 2020). More research is needed to assess the meaning and the processes associated to dual identities among a larger array of immigrant minority groups, and across receiving societies differing in their openness to cultural diversity (Green \& Staerklé, 2013).

By considering the articulation of multiple identity dynamics following intergroup contact, the present study advances our understanding of the underlying mechanisms responsible for support for ethnic activism among minority group members. Nevertheless, a number of limitations must be acknowledged. Both the lack of representativeness of our sample and the cross-sectional nature of the data limit our conclusions. For instance, our participants reported relatively high socioeconomic status. As compared to other co-ethnics living in
Switzerland, it is therefore plausible that their relative financial gratification might have inflated the feelings that Kosovo Albanians are fairly treated. Yet, the overall support for ethnic activism in our sample was relatively high, and results were robust while controlling for a number of sociodemographic variables. Moreover, socioeconomic status was unrelated to level of national, ethnic, and dual identification, further supporting our interpretations. Other than only recruiting larger and more representative samples, longitudinal designs with cohorts of new Kosovo Albanian immigrants would be needed to properly study the emergence of dual identity in relationship with intergroup contact opportunities and support for ethnic activism (see e.g., Tropp et al., 2012). Furthermore, future studies should examine more systematically the role of host national citizenship in explaining the sedative effects of intergroup contact on support for ethnic activism.

\section{5 | CONCLUSION}

The perceived compatibility between ethnic and national identities among immigrants is an important marker of psychological adaptation. Yet, the gradual and repetitive contact with members of the national majority group risks to move dual identifiers away from supporting ethnic activism. By promoting more egalitarian societies, immigrant minorities are not solely defending the vested interest of the disadvantaged ethnic group, but they serve the general interest of receiving societies as well. Not only immigrant minorities may benefit from actively participating in the political arena, but also society as a whole may benefit from addressing the needs of the immigrant population. Policymakers should therefore promote political engagement of immigrant minorities with different migration origins and trajectories, by framing ethnic activism as the ultimate proof of integration of immigrant minorities into the body politics.

\section{ACKNOWLEDGMENTS}

The first and second authors equally contributed to the paper. Many thanks to Gezim Misini for handling the data collection. Thanks also to the people who provided helpful support in the translation of the questionnaires procedure.

\section{ORCID}

Emanuele Politi iD https://orcid.org/0000-0002-8577-3197

Eva G. T. Green (iD https://orcid.org/0000-0003-1516-0157

Edona Maloku iD https://orcid.org/0000-0001-5961-8671

\section{REFERENCES}

Albzour, M., Penic, S., Nasser, R., \& Green, E. G. T. (2019). Support for "normalization" of relations between Palestinians and Israelis, and how it relates to contact and resistance in the west bank. Journal of Social and Political Psychology, 7, 978-996. https://doi.org/10.5964/jspp.v7i2.877

Benet-Martínez, V., \& Haritatos, J. (2005). Bicultural Identity Integration (BII): Componentsand psychosocialantecedents.Journal of Personality, 73, 1015-1049. https://doi.org/10.1111/j.1467-6494.2005.00337.x

Berry, J. W., Phinney, J. S., Sam, D. L., \& Vedder, P. (2006). Immigrant youth in cultural transition: Acculturation, identity and adaptation across national contexts. Mahwah, NJ: Lawrence Erlbaum Associates Publishers. 
Bevelander, P. (2011). Naturalisation and social inclusion. In OECD (Ed.), Naturalisation: A passport for the better Integration of Immigrants? (pp. 237-248). Paris: OECD Publishing. https://doi.org/10.1787/97892 64099104-en

Brown, R., \& Hewstone, M. (2005). An integrative theory of intergroup contact. Advances in Experimental Social Psychology, 37, 255-343. https://doi.org/10.1016/S0065-2601(05)37005-5

Burri Sharani, B., Efionavi-Mäder, D., Hammer, S., Pecoraro, M., Soland, B., Tsaka, A., \& Wyssmüller, C. (2010). Die kosovarische Bevölkerung in der Schweiz [The Kosovar population in Switzerland]. Retrieved from https://www.sem.admin.ch/dam/data/sem/publiservice/publi kationen/diaspora/diasporastudie-kosovo-d.pdf

Çakal, H., Eller, A., Sirlopú, D., \& Pérez, A. (2016). Intergroup relations in Latin America: Intergroup contact, common ingroup identity, and activism among indigenous groups in Mexico and Chile. Journal of Social Issues, 72, 355-375. https://doi.org/10.1111/josi.12170

Çakal, H., Hewstone, M., Schwär, G., \& Heath, A. (2011). An investigation of the social identity model of collective action and the "sedative" effect of intergroup contact among Black and White students in South Africa. British Journal of Social Psychology, 50, 606-627. https://doi. org/10.1111/j.2044-8309.2011.02075.x

Chipeaux, M., Kulich, C., Iacoviello, V., \& Lorenzi-Cioldi, F. (2017). "I Want, therefore I am "-Anticipated upward mobility reduces ingroup concern. Frontiers in Psychology, 8, 1-14. https://doi.org/10.3389/ fpsyg.2017.01451

Cola, M., Iseni, B., \& Brusa, M. M. (2012). The Kosovar diaspora in Switzerland: Construction of identities between media use and diasporic traits. Revista Română de Comunicare Şi Relaţii Publice, 14, 47-63. Retrieved from http://journalofcommunication.ro/oldsite/ archive2/028/28/rjcpr_28_full.pdf\#page=7

Cortina, J. M. (1993). What is coefficient alpha? An examination of theory and applications. Journal of Applied Psychology, 78, 98-104. https:// doi.org/10.1037/0021-9010.78.1.98

Curtin, N., Kende, A., \& Kende, J. (2016). Navigating multiple identities: The Simultaneous Influence Of Advantaged And Disadvantaged Identities On Politicization And Activism. Journal of Social Issues, 72, 264-285. https://doi.org/10.1111/josi.12166

Dahinden, J., \& Moret, J. (2008). Les activités transnationales des associations de migrants serbes et kosovars en Suisse [The transnational activities of associations of Serbian and Kosovar immigrants in Switzerland]. Annuaire Suisse de Politique de Développement, 27, 227238. Retrieved from https://journals.openedition.org/aspd/pdf/650

Derks, B., Van Laar, C., Ellemers, N., \& Raghoe, G. (2015). Extending the Queen Bee effect: How Hindustani workers cope with disadvantage by distancing the self from the group. Journal of Social Issues, 71, 476496. https://doi.org/0.1111/josi.12124

Di Bernardo, G. A., Vezzali, L., Stathi, S., McKeown Jones, S., Cocco, V. M., Saguy, T., \& Dixon, J. (2019). Fostering social change among advantaged and disadvantaged group members: Integrating intergroup contact and social identity perspectives on collective action. Group Processes and Intergroup Relations. https://doi.org/10.1177/13684 30219889134

Dixon, J., Cakal, H., Khan, W., Osmany, M., Majumdar, S., \& Hassan, M. (2017). Contact, political solidarity and collective action: An Indian case study of relations between historically disadvantaged communities. Journal of Community and Applied Social Psychology, 27, 83-95. https://doi.org/10.1002/casp.2296

Dixon, J., Durrheim, K., Tredoux, C., Tropp, L., Clack, B., \& Eaton, L. (2010). A paradox of integration? Interracial contact, prejudice reduction, and perceptions of racial discrimination. Journal of Social Issues, 66 , 401-416. https://doi.org/10.1111/j.1540-4560.2010.01652.x

Dovidio, J. F., Gaertner, S. L., Shnabel, N., Saguy, T., \& Johnson, J. (2010). Recategorization and prosocial behavior: Common in-group identity and a dual identity. In S. Stürmer \& M. Snyder (Eds.), The psychology of prosocial behavior: Group processes, intergroup relations, and helping (pp. 191-207). Malden: Blackwell.

Durrheim, K., Jacobs, N., \& Dixon, J. (2014). Explaining the paradoxical effects of intergroup contact: Paternalistic relations and system justification in domestic labour in South Africa. International Journal of Intercultural Relations, 41, 150-164. https://doi.org/10.1016/j.ijint rel.2013.11.006

Ellemers, N. (1993). The influence of socio-structural variables on identity management strategies. European Review of Social Psychology, 4, 27-57. https://doi.org/10.1080/14792779343000013

Ellemers, N., Spears, R., \& Doosje, B. (1997). Sticking together of falling apart: In-group identification as a psychological determinant of group commitment versus individual mobility. Journal of Personality and Social Psychology, 72, 617-626. https://doi. org/10.1037//0022-3514.72.3.617

Fibbi, R., \& Truong, J. (2015). Parental involvement and educational success in Kosovar families in Switzerland. Comparative Migration Studies, 3, 1-17. https://doi.org/10.1186/s40878-015-0010-y

Glasford, D. E., \& Dovidio, J. F. (2011). E pluribus unum: Dual identity and minority group members' motivation to engage in contact, as well as social change. Journal of Experimental Social Psychology, 47, 1021-1024. https://doi.org/10.1016/j.jesp.2011.03.021

González, R., \& Brown, R. (2003). Generalization of positive attitude as a function of subgroup and superordinate group identifications in intergroup contact. European Journal of Social Psychology, 33, 195-214. https://doi.org/10.1002/ejsp.140

Green, E. G. T., \& Staerklé, C. (2013). Migration and multiculturalism. In L. Huddy, D. O. Sears, \& J. Levy (Eds.), Oxford handbook of political psychology (pp. 852-889). Oxford: Oxford University Press.

Guimond, S., de laSablonnière, R., \& Nugier, A. (2014). Living in a multicultural world: Intergroup ideologies and the societal context of intergroup relations. European Review of Social Psychology, 25, 142-188. https://doi.org/10.1080/10463283.2014.957578

Hainmueller, J., Hangartner, D., \& Pietrantuono, G. (2015). Naturalization fosters the long-term political integration of immigrants. Proceedings of the National Academy of Sciences, 112, 12651-12656. https://doi. org/10.1073/pnas.1418794112

Hainmueller, J., Hangartner, D., \& Pietrantuono, G. (2017). Catalyst or crown: Does naturalization promote the long-term social integration of immigrants?American Political Science Review, 111, 256-276. https://doi.org/10.1017/S0003055416000745

Harwood, J., Hewstone, M., Paolini, S., \& Voci, A. (2005). Grandparentgrandchild contact and attitudes toward older adults: Moderator and mediator effects. Personality and Social Psychology Bulletin, 31, 393-406. https://doi.org/10.1177/0146167204271577

Hässler, T., Ullrich, J., Bernardino, M., Shnabel, N., Laar, C. V., Valdenegro, D., ... Ugarte, L. M. (2020). A large-scale test of the link between intergroup contact and support for social change. Nature Human Behaviour. https://doi.org/10.1038/s41562-019-0815-z

Hayes, A. F. (2018). Introduction to mediation, moderation and conditional process analysis (2nd ed.). London, UK: Guilford Press.

Hayward, L. E., Hornsey, M. J., Tropp, L. R., \& Barlow, F. K. (2017). Positive and negative intergroup contact predict Black and White Americans' judgments about police violence against Black Americans. Journal of Applied Social Psychology, 47, 605-615. https://doi.org/10.1111/ jasp.12463

Hewstone, M., \& Swart, H. (2011). Fifty-odd years of inter-group contact: From hypothesis to integrated theory. British Journal of Social Psychology, 50, 374-386. https://doi.org/10.1111/j.2044-8309. 2011.02047.x

Hopkins, N., \& Kahani-Hopkins, V. (2006). Minority group members' theories of intergroup contact: A case study of British Muslims' conceptualizations of "Islamophobia" and social change. British Journal of Social Psychology, 45, 245-264. https://doi.org/10.1348/014466605X48583 
Jenkins, S. T., Reysen, S., \& Katzarska-Miller, I. (2012). Ingroup identification and personality. Journal of Interpersonal Relations, Intergroup Relations and Identity, 5, 9-16. Retrieved from http://www.academia. edu/download/31701599/Jenkins_2012.pdf

Johnson, P. O., \& Neyman, J. (1936). Test of certain linear hypotheses and their applications to some educational problems. In J. Neyman \& O. Christ (Eds.), Statistical research memories (pp. 57-93). Cambridge, UK: Cambridge University Press.

Kauff, M., Green, E. G. T., Schmid, K., Hewstone, M., \& Christ, O. (2016). Effects of majority members' positive intergroup contact on minority members' support for ingroup rights: Mobilizing or demobilizing effects?European Journal of Social Psychology, 46, 833-839. https://doi. org/10.1002/ejsp.2194

Kolbe, M., \& Crepaz, M. M. L. (2016). The power of citizenship: How immigrant incorporation affects attitudes towards social benefits. Comparative Politics, 49, 105-123. https://doi.org/10.5129/00104 1516819582937

Koopmans, R., Statham, P., Giugni, M., \& Passy, F. (2005). Contested citizenship: Immigration and cultural diversity in Europe. Minneapolis, MN: University of Minnesota Press.

Kulich, C., Lorenzi-Cioldi, F., \& lacoviello, V. (2015). Moving across status lines: Low concern for the ingroup and group identification. Journal of Social Issues, 71, 453-475. https://doi.org/10.1111/josi.12123

Mähönen, T. A., \& Jasinskaja-Lahti, I. (2015). The ironic effect of national identification on support for collective action. European Journal of Social Psychology, 45, 567-574. https://doi.org/10.1002/ ejsp. 2118

Maloku, E., Derks, B., Van Laar, C., \& Ellemers, N. (2016). Building national identity in newborn Kosovo: Challenges of integrating national identity with ethnic identity among Kosovar Albanians and Kosovar Serbs. In S. McKeown, R. Haji, \& N. Ferguson (Eds.), Understanding peace and conflict through social identity theory (pp. 245-260). New York, NY: Springer.

Martiny, S. E., Froehlich, L., Deaux, K., \& Mok, S. Y. (2017). Defining ethnic, national, and dual identities: Structure, antecedents, and consequences of multiple social identities of Turkish-origin high school students in Germany. Journal of Community and Applied Social Psychology, 27, 400-410. https://doi.org/10.1002/casp.2318

Nicolet, L., \& Barth, N. (2018, November 5). L'identité multiple [Multiple identity]. Migros Magazine, 45, 10-15. Retrieved from https://www. migrosmagazine.ch/debat-double-nationalite-identite-suisse

Pantoja, A. D., \& Gershon, S. A. (2006). Political orientations and naturalization among Latino and Latina immigrants. Social Science Quarterly, 87, 1171-1187. https://doi.org/10.1111/j.1540-6237. 2006.00422.x

Pereira, A., Green, E. G. T., \& Visintin, E. P. (2017). National identification counteracts the sedative effect of positive intergroup contact on ethnic activism. Frontiers in Psychology, 8, 1-10. https://doi. org/10.3389/fpsyg.2017.00477

Pettigrew, T. F., \& Tropp, L. R. (2006). A meta-analytic test ofintergroup contact theory. Journal of Personality and Social Psychology, 90, 751783. https://doi.org/10.1037/0022-3514.90.5.751

Phinney, J. S. (1990). Ethnic identity in adolescents and adults: Review of research. Psychological Bulletin, 108, 499-514. https://doi. org/10.1037/0033-2909.108.3.499

Politi, E., Chipeaux, M., Lorenzi-Cioldi, F., \& Staerklé, C. (2020). More royalist than the king? Immigration policy attitudes among naturalized citizens. Political Psychology. https://doi.org/10.1111/pops.12642

Politi, E., Roblain, A., Gale, J., Licata, L., \& Staerklé, C. (2020). If you want to be one of us, then become like us: The evaluation of naturalization applicants by host nationals. European Journal of Social Psychology. https://doi.org/10.1002/ejsp.2663

Reimer, N. K., Becker, J. C., Benz, A., Christ, O., Dhont, K., Klocke, U., ... Hewstone, M. (2017). Intergroup contact and social change:
Implications of negative and positive contact for collective action in advantaged and disadvantaged groups. Personality and Social Psychology Bulletin, 43, 121-136. https://doi.org/10.1177/01461 67216676478

Reysen, S., Slobodnikova, A., \& Katzarska-Miller, I. (2016). Interaction of socio-structural characteristics to predict Roma's identification and desire to challenge low status position. Journal of Applied Social Psychology, 46, 428-434. https://doi.org/10.1111/jasp.12373

Saguy, T., Tausch, N., Dovidio, J. F., \& Pratto, F. (2009). The irony of harmony: Intergroup contact can produce false expectations for equality. Psychological Science, 20, 114-122. https://doi. org/10.1111/j.1467-9280.2008.02261.x

Scuzzarello, S. (2015). Political participation and dual identification among migrants. Journal of Ethnic and Migration Studies, 41, 12141234. https://doi.org/10.1080/1369183X.2015.1022517

Sengupta, N. K., \& Sibley, C. G. (2013). Perpetuating one's own disadvantage: Intergroup contact enables the ideological legitimation of inequality. Personality and Social Psychology Bulletin, 39, 1391-1403. https://doi.org/10.1177/0146167213497593

Simon, B., \& Grabow, O. (2010). The politicization of migrants: Further evidence that politicized collective identity is a dual identity. Political Psychology, 31, 717-738. https://doi. org/10.1111/j.1467-9221.2010.00782.x

Simon, B., \& Klandermans, B. (2001). Politicized collective identity: A social psychological analysis. American Psychologist, 56, 319-331. https://doi.org/10.1037/0003-066X.56.4.319

Simon, B., Reichert, F., \& Grabow, O. (2013). When dual identity becomes a liability: Identity and political radicalism among migrants. Psychological Science, 24, 251-257. https://doi.org/10.1177/09567 97612450889

Simon, B., \& Ruhs, D. (2008). Identity and politicization among Turkish migrants in Germany: The role of dual identification. Journal of Personality and Social Psychology, 95, 1354-1366. https://doi. org/10.1037/a0012630

Steinhardt, M. F., \& Wedemeier, J. (2012). The labor market performance of naturalized immigrants in Switzerland: New findings from the Swiss labor force survey. International Migration \& Integration, 13, 223-242. https://doi.org/10.1007/s12134-011-0213-5

Stott, C., \& Drury, J. (2004). The importance of social structure and social interaction in stereotype consensus and content: Is the whole greater than the sum of its parts?European Journal of Social Psychology, 34, 11-23. https://doi.org/10.1002/ejsp.183

Tajfel, H., \& Turner, J. C. (1979). An integrative theory of intergroup conflict. In G. Austin \& S. Worchel (Eds.), The social psychology of intergroup relations (pp. 33-47). Monterey, CA: Brooks/Cole.

Tausch, N., Saguy, T., \& Bryson, J. (2015). How does intergroup contact affect social change? Its impact on collective action and individual mobility intentions among members of a disadvantaged group. Journal of Social Issues, 71, 536-553. https://doi.org/10.1111/ josi.12127

Tropp, L. R., Hawi, D. R., Van Laar, C., \& Levin, S. (2012). Cross-ethnic friendships, perceived discrimination, and their effects on ethnic activism over time: A longitudinal investigation of three ethnic minority groups. British Journal of Social Psychology, 51, 257-272. https://doi. org/10.1111/j.2044-8309.2011.02050.x

Wanner, P., \& Steiner, I. (2012). La naturalisation en Suisse. Evolution 19922010 [Naturalization in Switzerland. Evolution from 1992 to 2010]. Berne: Commission Fédérale pour les Questions de Migration. Retrieved from http://archive-ouverte.unige.ch/unige:39718

Wright, S. C., \& Baray, G. (2012). Models of social change in social psychology: Collective action or prejudice reduction, conflict or harmony. In J. Dixon \& M. Levine (Eds.), Beyond prejudice: Extending the social psychology of conflict, inequality and social change (pp. 225-247). Cambridge, UK: Cambridge University Press. 
Wright, S. C., \& Lubensky, M. E. (2009). The struggle for social equality: Collective action versus prejudice reduction. In S. Demoulin, J. P. Leyens, \& J. F. Dovidio (Eds.), Intergroup misunderstandings: Impact of divergent social realities (pp. 291-310). New York, NY: Psychology Press.

Zomeren, M. V., Spears, R., \& Leach, C. W. (2008). Exploring psychological mechanisms of collective action: Does relevance of group identity influence how people cope with collective disadvantage?British Journal of Social Psychology, 47, 353-372. https://doi.org/10.1348/01446 $6607 \times 231091$
How to cite this article: PolitiE, GiroudA, GreenEGT,

MalokuE. Sedative effects of intergroup contact on support for ethnic activism among Kosovo Albanians in Switzerland: The interplay of ethnic, national, and dual identification.

J Appl Soc Psychol. 2020;50:418-429.

https://doi.org/10.1111/jasp.12670 